\title{
Specify Site of New Tumor Event
}

National Cancer Institute

\section{Source}

National Cancer Institute. Specify Site of New Tumor Event. NCI Thesaurus. Code C156854.

A directive to specify the anatomic site of a new tumor event. 